\title{
Relation between Tracer Diffusivity and Electrical Conductivity on Multi-component Oxide Slags at $900^{\circ}$ to $1600^{\circ} \mathrm{C}^{*}$
}

\section{By Kazuhiro S. GOTO, ${ }^{* *}$ Minoru SASABE ${ }^{* * *}$ and Masahiro KAWAKAMI**}

\section{Object of the Present Communication}

When the micro-mechanism on the transport of ionic species is the same for the electrical conduction and for the tracer diffusion in the ionic solutions, one can derive ${ }^{1)}$ a simple relation between the conductivity and the diffusivity, called Nernst-Einstein relation:

$$
\sigma=\frac{n_{i}\left(z_{i} e\right)^{2}}{k T f t_{i}} D_{i}^{\operatorname{tr}}
$$

where, $\quad \sigma:$ the conductivity in $A \cdot V^{-1} \cdot \mathrm{cm}^{-1}$

$D_{i}^{\text {tr }}:$ the tracer diffusivity of an ionic species $i$ in $\mathrm{cm}^{2} \cdot \mathrm{sec}^{-1}$

$n_{i}, z_{i}$ and $t_{i}$ : concentration, valency and transference number of the ionic species, respectively

$e:$ the unit charge $\left(1.6 \times 10^{-19} \mathrm{~A}\right.$. sec)

$k$ : Boltzmann constant $\left(1.38 \times 10^{-23}\right.$ $\mathrm{V} \cdot \mathrm{A} \cdot \sec ^{\circ} \mathrm{K}^{-1}$ )

$T$ : the absolute temperature

$f$ : the correlation factor ${ }^{2,3}$ of successive jumps of the tracer.

Its validity has been proved on solid halides ${ }^{4}$ and liquid halides. ${ }^{5-7)}$

The object of the present communication is to examine the validity of the relation on multi-component oxide slags. For this purpose, used are 29 sets of independent experimental data of the conductivity and the diffusivity at $900^{\circ}$ to $1600^{\circ} \mathrm{C}$.

\section{Tracer Diffusivities, Measured and Calculated}

The validity of Nernst-Einstein relation can be examined by comparing the measured tracer diffusivities of a cation with those calculated from the electrical conductivities. Here, $\mathrm{Na}_{2} \mathrm{O}-\mathrm{GeO}_{2}, \mathrm{Na}_{2} \mathrm{O}$ $\mathrm{SiO}_{2}, \mathrm{CaO}-\mathrm{SiO}_{2}$ and $\mathrm{CaO}-\mathrm{SiO}_{2}-\mathrm{Al}_{2} \mathrm{O}_{3}$ are selected with this respect. In the calculation, it is assumed that $f$ and the transference number of $\mathrm{Na}^{+}$or $\mathrm{Ca}^{2+}$ would be unity.

Results of the calculation are shown in $D_{\text {calc }}$. column of Table 1, while the sources of the used data are listed in Table 2. The corresponding measured tracer diffusivities are listed in $D_{\text {meas }}$. column of Table 1, where three data from different sources are cited with respect to $\mathrm{CaO}-\mathrm{SiO}_{2}-\mathrm{Al}_{2} \mathrm{O}_{3}$. Data of $D_{\text {meas. }}$. are plotted against $D_{\text {calc. }}$ in Fig. 1. From the figure, one can see that every $D_{\text {meas. }}$ is smaller than $D_{\text {calc. }}$.
The relative deviations, defined by $\left\{\left(D_{\text {meas. }}-D_{\text {calc. }}\right)\right\}$ $D_{\text {calc. }} \times 100$, are listed in the right column to $D_{\text {calc }}$. of Table 1. From the column, it is noted that the deviations are nearly the same among binary oxide slags, i.e., $-70 \pm 20 \%$, regardless of composition and temperature, and that the deviations are $-28 \pm 9 \%$ in $\mathrm{CaO}-\mathrm{SiO}_{2}-\mathrm{Al}_{2} \mathrm{O}_{3}$. Further, it can be said that the activation energy for the tracer diffusion is larger than that for the electrical conduction.

\section{An Interpretation of the Deviation}

The calculation was based on many assumptions. The transference number of $\mathrm{Na}^{+}$or $\mathrm{Ca}^{2+}$ was taken as unity. According to the compilation by Adachi and Ogino, ${ }^{21)} t_{\mathrm{K}^{+}}$in $\mathrm{K}_{2} \mathrm{O}-\mathrm{SiO}_{2}, t_{\mathrm{Li}^{+}}$in $\mathrm{Li}_{2} \mathrm{O}-\mathrm{SiO}_{2},{ }^{22)}$ $t_{\mathrm{Ca}^{2+}}$ in $\mathrm{CaO}-\mathrm{SiO}_{2}$ and $\mathrm{CaO}-\mathrm{SiO}_{2}-\mathrm{Al}_{2} \mathrm{O}_{3}{ }^{23)}$ can be taken as unity. It seems quite reasonable to assume $t_{\mathrm{Na}^{+}}$as unity in $\mathrm{Na}_{2} \mathrm{O}-\mathrm{GeO}_{2}$ and $\mathrm{Na}_{2} \mathrm{O}-\mathrm{SiO}_{2}$ from the data.

Correlation factor $f$ was assumed unity, because there would be much more cation vacancies in molten slag than in solid lattice.

If the diffusivity measurement suffered from some convection in the molten slag, the apparent diffusivity would be larger than the true value. Thus, the deviation should be in the opposite direction.

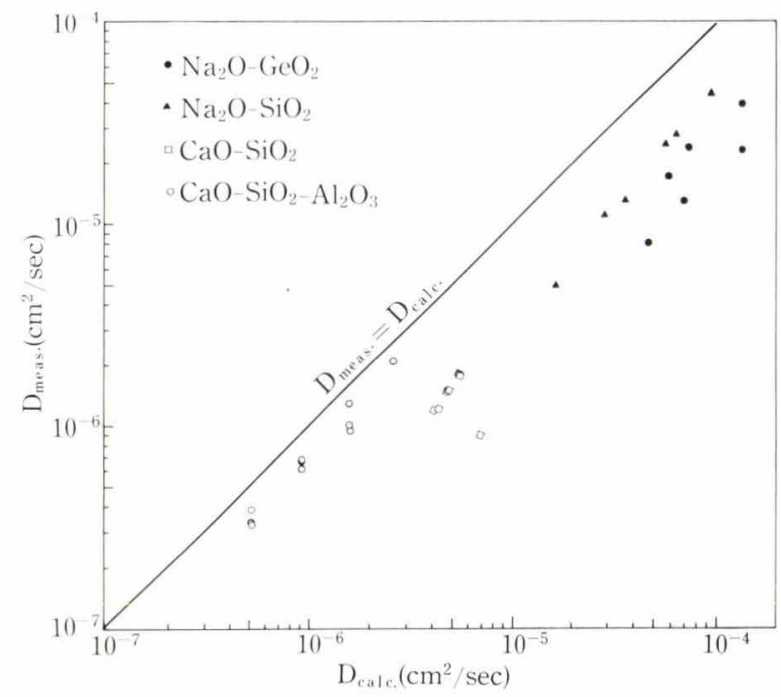

Fig. 1. Comparison between tracer diffusivities, measured and calculated from the electrical conductivity data using Nernst-Einstein relation

* Received October 18, 1976.

** Department of Metallurgical Engineering, Faculty of Engineering, Tokyo Institute of Technology, Ōokayama, Meguro-ku, Tokyo 152.

*** Department of Metallurgical Engineering, Chiba Institute of Technology, Yatsu-machi, Narashino 275. 
Table 1. Tracer diffusivity, measured and calculated from the electrical conductivity

\begin{tabular}{|c|c|c|c|c|c|c|c|}
\hline No. & $\begin{array}{l}\text { Composition } \\
\text { (Diffusing species) }\end{array}$ & $\begin{array}{l}\text { Temp. } \\
\left({ }^{\circ} \mathrm{C}\right)\end{array}$ & $\begin{array}{c}D_{\text {meas. }} \\
\left(\mathrm{cm}^{2} / \mathrm{sec}\right)\end{array}$ & $\begin{array}{c}D_{\text {ealc. }} \\
\left(\mathrm{cm}^{2} / \mathrm{sec}\right)\end{array}$ & $\begin{array}{l}\text { Relative } \\
\text { deviation* } \\
(\%)\end{array}$ & $\underset{(\mathrm{kcal} / \mathrm{mol})}{Q_{d}}$ & $\begin{array}{c}Q_{c} \\
(\mathrm{kcal} / \mathrm{mol})\end{array}$ \\
\hline $\begin{array}{l}1 \\
2 \\
3\end{array}$ & $\underset{\left(\mathrm{Na}^{+}\right)}{40 \mathrm{~mol}} \% \mathrm{Na}_{2} \mathrm{O}-60 \mathrm{~mol} \% \mathrm{GeO}_{2}$ & $\begin{array}{l}1200 \\
1100 \\
1000\end{array}$ & $\begin{array}{l}3.9 \times 10^{-5} \\
2.4 \\
1.7\end{array}$ & $\begin{array}{l}13.3 \times 10^{-5} \\
7.3 \\
5.9\end{array}$ & $\begin{array}{l}-71 \\
-67 \\
-71\end{array}$ & 10.5 & 9.6 \\
\hline $\begin{array}{l}4 \\
5 \\
6\end{array}$ & $\underset{\left(\mathrm{Na}^{+}\right)}{30 \mathrm{~mol} \% \mathrm{Na}_{2} \mathrm{O}-70 \mathrm{~mol} \% \mathrm{GeO}_{2}}$ & $\begin{array}{l}1200 \\
1100 \\
1000\end{array}$ & $\begin{array}{l}2.3 \times 10^{-5} \\
1.2 \\
0.8\end{array}$ & $\begin{array}{l}13.3 \times 10^{-5} \\
7.0 \\
4.7\end{array}$ & $\begin{array}{l}-85 \\
-83 \\
-83\end{array}$ & 14.2 & 10.5 \\
\hline $\begin{array}{l}7 \\
8 \\
9\end{array}$ & $\underset{\left(\mathrm{Na}^{+}\right)}{34 \mathrm{wt} \%} \% \mathrm{Na}_{2} \mathrm{O}-66 \mathrm{wt} \% \mathrm{SiO}_{2}$ & $\begin{array}{r}1300 \\
1100 \\
900\end{array}$ & $\begin{array}{l}4.4 \times 10^{-5} \\
2.5 \\
1.1\end{array}$ & $\begin{array}{l}9.6 \times 10^{-5} \\
5.6 \\
2.9\end{array}$ & $\begin{array}{l}-54 \\
-55 \\
-62\end{array}$ & 12.5 & 11.2 \\
\hline $\begin{array}{l}10 \\
11 \\
12\end{array}$ & $\underset{\left(\mathrm{Na}^{+}\right)}{24 \mathrm{wt}} \% \mathrm{Na}_{2} \mathrm{O}-76 \mathrm{wt} \% \mathrm{SiO}_{2}$ & $\begin{array}{r}1300 \\
1100 \\
900\end{array}$ & $\begin{array}{l}2.8 \times 10^{-5} \\
1.3 \\
0.5\end{array}$ & $\begin{array}{l}6.7 \times 10^{-5} \\
3.7 \\
1.7\end{array}$ & $\begin{array}{l}-58 \\
-65 \\
-71\end{array}$ & 16.1 & 12.5 \\
\hline 13 & $55 w t \% \mathrm{CaO}-45 w t \% \mathrm{SiO}_{2}\left(\mathrm{Ca}^{2+}\right)$ & 1500 & $0.9 \times 10^{-6}$ & $7.0 \times 10^{-6}$ & -87 & $50 \pm 20$ & 35 \\
\hline $\begin{array}{l}14 \\
15 \\
16\end{array}$ & $\begin{array}{c}54 \mathrm{wt} \% \mathrm{CaO}-46 \mathrm{wt} \% \mathrm{SiO}_{2} \\
\left(\mathrm{Ca}^{2+}\right)\end{array}$ & $\begin{array}{l}1600 \\
1575 \\
1550\end{array}$ & $\begin{array}{l}1.8 \times 10^{-6 * *} \\
1.5 \\
1.2\end{array}$ & $\begin{array}{l}5.3 \times 10^{-6} \\
4.7 \\
4.3\end{array}$ & $\begin{array}{l}-66 \\
-68 \\
-72\end{array}$ & $50 \pm 20$ & 26 \\
\hline $\begin{array}{l}17 \\
18 \\
19\end{array}$ & $\underset{\left(\mathrm{Ca}^{2+}\right)}{57 \mathrm{wt} \% \mathrm{CaO}-43 \mathrm{siO}{ }_{2}}$ & $\begin{array}{l}1600 \\
1575 \\
1500\end{array}$ & $\begin{array}{l}1.8 \times 10^{-6 * *} \\
1.5 \\
1.2\end{array}$ & $\begin{array}{l}5.3 \times 10^{-6} \\
4.7 \\
4.0\end{array}$ & $\begin{array}{l}-66 \\
-68 \\
-70\end{array}$ & $50 \pm 20$ & 35 \\
\hline $\begin{array}{l}20 \\
21 \\
22\end{array}$ & & 1350 & $\begin{array}{l}3.3 \times 10^{-7} \\
3.3 \\
3.9\end{array}$ & $5.2 \times 10^{-7}$ & $\begin{array}{l}-37 \\
-37 \\
-25\end{array}$ & $\begin{array}{l}70 \pm 20 \\
30 \pm 15 \\
50 \pm 20\end{array}$ & 46 \\
\hline $\begin{array}{l}23 \\
24 \\
25\end{array}$ & $\begin{array}{c}40 \mathrm{wt} \% \mathrm{CaO}-40 \mathrm{wt} \% \mathrm{SiO}_{2}- \\
20 \mathrm{wt}^{-} \mathrm{Al}_{2} \mathrm{O}_{3} \\
\left(\mathrm{Ca}^{2+}\right)\end{array}$ & 1400 & $\begin{array}{l}6.8 \times 10^{-7} \\
6.2 \\
6.9\end{array}$ & $9.2 \times 10^{-7}$ & $\begin{array}{l}-26 \\
-33 \\
-25\end{array}$ & $\begin{array}{l}70 \pm 20 \\
30 \pm 15 \\
50 \pm 20\end{array}$ & 46 \\
\hline $\begin{array}{l}26 \\
27 \\
28\end{array}$ & & 1450 & $\begin{array}{l}1.3 \times 10^{-6} \\
9.5 \times 10^{-7} \\
1.0 \times 10^{-6}\end{array}$ & $1.6 \times 10^{-6}$ & $\begin{array}{l}-19 \\
-37 \\
-37\end{array}$ & $\begin{array}{l}70 \pm 20 \\
30 \pm 15 \\
50 \pm 20\end{array}$ & 46 \\
\hline 29 & & 1500 & $2.1 \times 10^{-6}$ & $2.6 \times 10^{-6}$ & -19 & $70 \pm 20$ & 46 \\
\hline
\end{tabular}

$\mathrm{SiO}_{2}$.

Table 2. Reference numbers on data sources of the tracer diffusivity, electrical conductivity and density used in Table 1.

\begin{tabular}{|c|c|c|c|}
\hline & $D^{\operatorname{tr}}$ & $\sigma$ & $\rho$ \\
\hline \multirow{5}{*}{$\begin{array}{l}\mathrm{Na}_{2} \mathrm{O}-\mathrm{GeO}_{2} \\
\mathrm{Na}_{2} \mathrm{O}-\mathrm{SiO}_{2} \\
\mathrm{CaO}-\mathrm{SiO}_{2} \\
\mathrm{CaO}-\mathrm{SiO}_{2}-\mathrm{Al}_{2} \mathrm{O}_{3}\end{array}$} & 9) & 10) & 11 \\
\hline & 12) & 13) & 12 \\
\hline & 14) & 15) & 16 \\
\hline & 14) & 19) & 16 \\
\hline & 18) 20) & & \\
\hline
\end{tabular}

If the Faradayic impedance at the interface between the electrodes and the molten slag were not negligible in the conductivity measurements, the conductivity would be smaller than the true value. Thus, the above errors would give the opposite deviation to Fig. 1 .

If ionic pair movement aided the diffusion like in liquid halides, ${ }^{4-7)}$ the measured diffusivity would be larger than that calculated from the conductivity, because the latter is not affected by the ionic pair movement.

Because all the above could not explain the deviation and the oxide slags are of multi-component, questionable is the validity of the fundamental assumption; The velocity of an ionic particle is proportional only to the force exerting upon the same ionic species, but not upon the other ionic species.

Generally, the diffusion flux of an ionic species $i$ in multi-component oxide slag, $j_{i}\left(\mathrm{~mol} \cdot \mathrm{cm}^{-\mathbf{2}} \cdot \mathrm{sec}^{-\mathbf{1}}\right)$, is given as, ${ }^{8)}$

$$
j_{i}=-\sum_{k=1}^{n} L_{i k} \frac{d \eta_{k}}{d x}+c_{i} v_{\circ}
$$

where, $L_{i k}$ : called transport coefficient in $\mathrm{mol}^{2}$. $\mathrm{cal}^{-1} \cdot \mathrm{cm}^{-1} \cdot \mathrm{sec}^{-1}$ 
$\eta_{k}$ : electrochemical potential of ionic species $k$ in $\mathrm{cal} \cdot \mathrm{mol}^{-1}$

$c_{i}:$ molar concentration of $i$ in $\mathrm{mol} \cdot \mathrm{cm}^{-3}$

$v_{\circ}$ : a local velocity of the internal reference frame in $\mathrm{cm} \cdot \mathrm{sec}^{-1}$

Goto, Schmalzried and Nagata, ${ }^{24,25)}$ Nagata and Goto $^{26)}$ derived the general relationship between $L_{i k}$ and $D_{i}^{\text {tr }}$, and also between $L_{i k}$ and $\sigma$. According to them, the tracer diffusivity of $i$ is given as

$$
D_{i}^{\mathrm{tr}}=\frac{R T}{c_{i}} L_{i i}
$$

The partial electrical conductivity due to ionic species $i$ is given as

$$
\sigma_{i}=F^{2} \sum_{k=0}^{3} z_{i} z_{k} L_{i k}
$$

where, $F$ is Faraday constant in cal $\cdot \mathrm{V}^{-1}$.equiv. ${ }^{-1}$ and A.sec.equiv. ${ }^{-1}$, suffix 1, 2, 3, 0 means, for example, $\mathrm{Ca}^{2+}, \mathrm{Si}^{4+}, \mathrm{Al}^{3+}$ and $\mathrm{O}^{2-}$ in $\mathrm{CaO}-\mathrm{SiO}_{2}-\mathrm{Al}_{2} \mathrm{O}_{3}$ liquid slag, and $z_{i}$ is the valency of $i$. In combination of Eq. (3) with Eq. (4), the relation, for the multi-component slags, between the electrical conductivity and the tracer diffusivity of $i$ can be given in terms of transport coefficients, for example, $\mathrm{CaO}-\mathrm{SiO}_{2}-\mathrm{Al}_{2} \mathrm{O}_{3}$, as

$$
\sigma_{1}=F^{2}\left({ }_{R T}^{4 c_{1}} D_{\mathrm{Ca}}^{\mathrm{tr}}+8 L_{12}+6 L_{13}-4 L_{10}\right)
$$

In comparison of Eq. (5) with Eq. (1), it is seen that $L_{12}, L_{13}$ and $L_{10}$ are omitted in the Nernst-Einstein relation. Therefore, the above deviation may be interpreted due to the neglection of the cross terms of $L_{12}$, $L_{13}$ and $L_{10}$. Also, Eq. (5) tells us that the activation energy for the conduction would not be the same as that for the diffusion because of the temperature dependence of the cross terms.

\section{REFERENCES}

1) A. B. Lidiard: Handbuch der Physik, Bd. XX, Springer Verlag, Berlin, (1957), 324.
2) J. Bardeen and C. Herring: Imperfections in Nearly Perfect Crystals, John Wiley \& Sons, New York, (1952), 261.

3) K. Compaan and Y. Haven: Trans. Faraday Soc., 52 (1956), 786.

4) D. Mapother, H. N. Crooks and R.J. Maurer: J. Chem. Phys., 18 (1950), 1234.

5) J. O'M. Bockris and G. W. Hooper: Dis. Farad. Soc., 32 (1961), 218.

6) J. O'M. Bockris, S. R. Richards and L. Nanis: J. Phys. Chem., 69 (1965), 1627.

7) G. Perkins, R. B. Escue, J. F. Lamb and J. W. Wimberley: J. Phys. Chem., 64 (1960), 1792.

8) L. Onsager: Trans. N.Y. Acad. Sci., 46 (1945), 241.

9) M. Sasabe and K. Kaneko: Tetsu-to-Hagané, 59 (1973), 190.

10) H. Saito: private communication (1972).

11) E. F. Riebling: J. Chem. Phys., 39 (1963), 3022.

12) Y. Gupta and T. B. King: Trans. Met. Soc. AIME, 239 (1967), 1701.

13) J. R. Hutchins: dissertation of Sc. Dr, M.I.T., (1959), cited in Ref. 12).

14) T. Saito and K. Maruya: J. Japan Inst. Metals, 21 (1957), 728.

15) Y. Matsushita and K. Mori: Tetsu-to-Hagané, 38 (1952), 283.

16) R. Kammel and H. Winterhager: Erzmetall., 18 (1965), 9.

17) H. Towers, M. Paris and J. Chipman: Trans. Met. Soc. AIME, 197 (1953), 1455.

18) K. Niwa: J. Japan Inst. Metals, 21 (1957), 304.

19) A. E. Martin and G. Derge: Trans. Met. Soc. AIME, 154 (1943), 104.

20) H. Towers and J. Chipman: Trans. Met. Soc. AIME, 209 (1957), 769 .

21) A. Adachi and K. Ogino: Yōyūen, 5 (1962), 1149.

22) J. O'M. Bockris, J. A. Kitchener and A. E. Davies: Trans. Farad. Soc., 48 (1952), 536.

23) O. A. Esin and A. K. Kirianov: Izv. Akad. Nauk. SSSR Otdel. Tekh. Nauk., (1955), No. 12, 28.

24) K. S. Goto, H. Schmalzried and K. Nagata: Tetsu-toHagané, 61 (1975), 2794.

25) K. S. Goto, H. Schmalzried and K. Nagata: Arch. Eisenhüttenw., 47 (1976), 133.

26) K. Nagata and K. S. Goto: J. Electrochem., 123 (1976), 1814. 